\title{
ANALISIS RASIO RNA/DNA UDANG WINDU Penaeus monodon HASIL SELEKSI TUMBUH CEPAT
}

\author{
Andi Parenrengi, Syarifuddin Tonnek, dan Andi Tenriulo \\ Balai Penelitian dan Pengembangan Budidaya Air Payau \\ Jl. Makmur Dg. Sitakka No. 129, Maros 90512, Sulawesi Selatan \\ E-mail: andi_parenrengi@hotmail.com
}

(Naskah diterima: 7 Januari 2013; Disetujui publikasi: 28 Februari 2013)

\begin{abstract}
ABSTRAK
Seleksi udang windu Penaeus monodon tumbuh cepat menggunakan marker DNA telah berhasil dilakukan dalam upaya perakitan strain unggul udang windu. Udang windu hasil seleksi menunjukkan adanya peningkatan pertumbuhan dibandingkan dengan tanpa seleksi (kontrol). Rasio RNA/DNA merupakan salah satu parameter yang telah banyak digunakan dalam menentukan kualitas ikan/udang di antaranya adalah pertumbuhan. Penelitian ini bertujuan untuk mengetahui rasio RNA/DNA pada udang windu hasil seleksi tumbuh cepat dan kontrol (tanpa seleksi). Sampel udang windu tumbuh cepat yang digunakan berukuran bobot $50,66 \pm 16,51 \mathrm{~g}$ dan panjang $17,55 \pm 1,93 \mathrm{~cm}$; sedangkan udang kontrol berukuran bobot 29,64 $\pm 11,93 \mathrm{~g}$ dan panjang $14,78 \pm 2,53 \mathrm{~cm}$. Metode isolasi total RNA dilakukan dengan menggunakan kit isogen, sedangkan genom DNA menggunakan metode konvensional fenol kloroform. Konsentrasi RNA dan DNA hasil isolasi diukur menggunakan GeneQuant. T-test dari Statistix Versi 3,0 digunakan untuk membedakan rasio RNA/DNA antara kedua perlakuan yang dianalisis. Hasil penelitian menunjukkan bahwa genom DNA dan total RNA mempunyai tingkat kemurnian yang tinggi. Hasil analisis t-test menunjukkan bahwa rasio RNA/DNA udang windu tumbuh cepat $(4,51)$ berbeda secara nyata $(P<0,05)$ dengan udang windu kontrol $(3,19)$. Kecenderungan rasio RNA/DNA semakin tinggi dengan semakin beratnya bobot badan, di mana rasio RNA/DNA udang betina $(4,96)$ lebih tinggi $(P<0,05)$ dari udang jantan $(2,93)$. Analisis regresi menunjukkan bahwa rasio $R N A / D N A$ udang windu memiliki hubungan erat dengan panjang $(R=0,5628)$ dan bobot $(R=0,6539)$. Hasil penelitian ini berimplikasi bahwa parameter rasio RNA/DNA dapat dijadikan sebagai indikator pertumbuhan udang windu.
\end{abstract}

KATA KUNCl: rasio RNA/DNA, panjang, bobot, udang windu, seleksi tumbuh cepat

ABSTRACT: Analysis of DNA, RNA, and RNA/DNA ratio on the black tiger shrimp Penaeus monodon from fast growing selection. By: Andi Parenrengi, Syarifuddin Tonnek, and Andi Tenriulo

Selection of black tiger shrimp Penaeus monodon for fast growing character using the DNA marker was successfully done in order to obtain the better strain of tiger shrimp. The selected shrimp showed the better growth rate than the non-selected shrimp (control). RNA/DNA ratio is widely useful method in order to assess the fish/ shrimp quality, including the growth rate. The study was conducted to determine the RNA/DNA ratio on tiger shrimp between the selected fast growing shrimp and nonselected shrimp. The tiger shrimp was collected from selected fast growing shrimp in weight of $50.66 \pm 16.51 \mathrm{~g}$ and length in $17.55 \pm 1.93 \mathrm{~cm}$, and the control shrimp in weight of $29.64 \pm 11.93 \mathrm{~g}$ and length in $14.78 \pm 2.53 \mathrm{~cm}$. RNA total was isolated by 
isogen kit, while DNA genome was isolated by conventional phenol-chloroform method. RNA and DNA concentration were calculated by GeneQuant. T-test program from Statistix Version 3.0 was performed to differ between treatments. Results showed that the extraction method used this study showed the high purity of DNA and RNA. The t-test revealed that the RNA/DNA ratio of fast growing black tiger shrimp (4.51) was significantly different $(P<0.05)$ with the control shrimp (3.19). The higher RNA/ $D N A$ ratio was obtained from the higher weight of tiger shrimp, where the female (4.96) showed the higher $R N A / D N A$ ratio $(P<0.05)$ than the male (2.93). Regression analysis showed the high relationship between $R N A / D N A$ ratio with body length $(R=0.5628)$ and body weight $(R=0.6539)$. The result of experiment implied that the $R N A / D N A$ ratio is useful indicator for growth rate of tiger shrimp.

\section{KEYWORDS: RNA/DNA ratio, body length, body weight, tiger shrimp, fast growing selection}

\section{PENDAHULUAN}

Udang windu Penaeus monodon merupakan salah satu spesies udang lokal yang telah banyak dibudidayakan di tambak-tambak air payau di Indonesia. Peningkatan produksi udang windu selain difokuskan pada upaya penanggulangan penyakit juga perlu dilakukan melalui upaya peningkatan laju pertumbuhannya. Peningkatan pertumbuhan udang windu dapat dilakukan melalui program seleksi dengan fokus pada karakter pertumbuhan. Perakitan strain udang windu unggul, khususnya tumbuh cepat melalui seleksi dapat dilakukan dengan menggunakan bantuan marker DNA atau dikenal dengan istilah marker assisted selection (MAS). Keberhasilan Balai Besar Penelitian dan Pengembangan Budidaya Laut (BBPPBL) Gondol, Bali dalam mengembangkan marker DNA dalam mendeteksi udang windu cepat tumbuh (Haryanti, 2011), merupakan langkah awal dalam menghasilkan udang windu yang memiliki pertumbuhan yang lebih cepat. Performa fenotip dan genotip udang windu yang membawa marker DNA tumbuh cepat tersebut telah dilaporkan oleh Haryanti et al. (2009). Hasil uji coba pembesaran larva udang windu hasil seleksi tumbuh cepat di Instalasi Tambak Percobaan Takalar, Balai Penelitian dan Pengembangan Budidaya Air Payau (BPPBAP) menunjukkan pertumbuhan udang windu hasil seleksi yang lebih tinggi 35,2\% dibandingkan dengan kontrol atau udang yang tidak membawa marker DNA tumbuh cepat (Tonnek, 2011). Oleh karena itu, diduga bahwa peran gen yang mengkode pertumbuhan pada udang sangat erat kaitannya dengan marker DNA yang telah dikembangkan sebagai MAS.
Sebagian besar pertumbuhan merupakan aktivitas sintesis protein yang secara genetik berlangsung pada sintesis RNA. Jika RNA disintesis secara aktif, maka pertumbuhan akan berlangsung lebih cepat. Oleh karena itu, kecepatan pertumbuhan udang sangat terkait dengan rasio konsentrasi RNA/DNA yang merupakan bentuk ekspresi karakter pertumbuhan udang tersebut. Analisis rasio RNA/ DNA telah banyak digunakan dalam penelitian evaluasi kualitas organisme termasuk ikan dan udang dan terdapat kecenderungan semakin besar rasio RNA/DNA semakin berkualitas larva ikan yang dihasilkan. Penilaian kualitas benih berdasarkan karakter rasio RNA/DNA telah dilakukan pada ikan gobi (Esteves et al., 2000), ikan mas Cyprinus carpio (Dewantoro, 2001), dan udang windu (Haryanti et al., 2006). Hubungan antara rasio RNA/DNA dengan laju pertumbuhan larva dan sintasan menunjukkan adanya korelasi positif pada beberapa spesies ikan (Buckley, 1984; Rooker \& Holt, 1996; Pepin et al., 1999; Caldarone et al., 2003). Selain itu, kajian rasio RNA/DNA juga telah digunakan untuk mengevaluasi pengukuran pertumbuhan jangka panjang pada populasi ikan (Haines, 1973) dan indeks yang dapat digunakan pada ekologi laut (Chicharo \& Chicharo, 2008). Rasio RNA/DNA juga telah dilaporkan sebagai indikator dalam mengevaluasi kondisi nutrisi yuwana moluska Ruditapes decussatus (Chicharo \& Chicharo, 1995) dan pemuasaan ikan sardin Sardinella brasiliensis (Rossi-Wongtschowski et al., 2003). Keberhasilan penggunaan rasio RNA/ DNA sebagai indikator kualitas komoditas perikanan telah banyak dilaporkan. Oleh karena itu, pengamatan rasio RNA/DNA perlu dilakukan dalam rangka penyediaan data dan informasi dalam komponen teknologi 
karakterisasi udang windu tumbuh cepat hasil seleksi.

\section{BAHAN DAN METODE}

\section{Sampel Udang}

Udang windu yang digunakan pada penelitian ini adalah udang windu hasil seleksi menggunakan marker DNA tumbuh cepat dan kontrol (udang windu yang tidak membawa marker DNA tumbuh cepat). Seleksi tersebut telah dilakukan di Balai Besar Penelitian dan Pengembangan Budidaya Laut, Gondol-Bali. Udang windu dengan karakter tumbuh cepat dan kontrol selanjutnya dipelihara di Instalasi Tambak Percobaan Balai Penelitian dan Pengembangan Budidaya Air Payau Takalar dengan mengacu standar prosedur operasional pembesaran udang windu. Udang windu dikoleksi secara acak dan selanjutnya diangkut secara hidup ke laboratorium untuk keperluan ekstraksi genom DNA dan total RNA. Bobot dan panjang sampel udang windu tumbuh cepat sebanyak sebelas ekor (5 ekor betina dan 6 ekor jantan) dan kontrol 13 ekor (6 ekor betina dan 7 ekor jantan) disajikan pada Tabel 1 .

\section{Ekstraksi Genom DNA}

Genom DNA udang windu diekstraksi dengan menggunakan metode fenol kloroform yang telah dikembangkan pada udang windu (Parenrengi et al., 2009a). Sebanyak 25 mg daging udang diambil secara aseptik dan

Tabel 1. Ukuran bobot dan panjang udang windu $P$. monodon yang digunakan untuk analisis DNA dan RNA

Table 1. Body weight and length of black tigershrimp P. monodon used for DNA and RNA analysis

\begin{tabular}{|c|c|c|c|c|c|c|c|}
\hline \multirow[t]{2}{*}{ No. } & $\begin{array}{l}\text { Kelamin } \\
\text { Sex }\end{array}$ & $\begin{array}{c}\text { Bobot } \\
\text { Weight } \\
\text { (g) }\end{array}$ & $\begin{array}{l}\text { Panjang } \\
\text { Length } \\
\quad(\mathrm{cm})\end{array}$ & \multirow[t]{2}{*}{ No. } & $\begin{array}{l}\text { Kelamin } \\
\text { Sex }\end{array}$ & $\begin{array}{l}\text { Bobot } \\
\text { Weight } \\
\text { (g) }\end{array}$ & $\begin{array}{l}\text { Panjang } \\
\text { Length } \\
\quad(\mathrm{cm})\end{array}$ \\
\hline & \multicolumn{3}{|c|}{ Kontrol (Control) } & & \multicolumn{3}{|c|}{ Tumbuh cepat (Fast growing) } \\
\hline 1 & \multirow{6}{*}{$\begin{array}{l}\text { Betina } \\
\text { Female }\end{array}$} & 18.2 & 11.5 & 1 & \multirow{6}{*}{$\begin{array}{l}\text { Betina } \\
\text { Female }\end{array}$} & 58.3 & 18.5 \\
\hline 2 & & 17.4 & 12.5 & 2 & & 68.4 & 19.5 \\
\hline 3 & & 14.7 & 12.0 & 3 & & 60.7 & 18.6 \\
\hline 4 & & 17.0 & 12.3 & 4 & & 64.6 & 19.4 \\
\hline 5 & & 45.2 & 17.4 & \multirow[t]{2}{*}{5} & & 70.9 & 19.6 \\
\hline 6 & & 41.7 & 17.6 & & & & \\
\hline \multicolumn{2}{|r|}{$\begin{array}{r}\text { Rataan } \pm S D \\
\text { Average } \pm S D\end{array}$} & $25.7 \pm 13.8$ & $13.9 \pm 2.8$ & \multicolumn{2}{|c|}{$\begin{array}{r}\text { Rataan } \pm S D \\
\text { Average } \pm S D\end{array}$} & $64.6 \pm 5.2$ & $19.1 \pm 0.5$ \\
\hline 7 & \multirow{7}{*}{$\begin{array}{l}\text { Jantan } \\
\text { Male }\end{array}$} & 12.6 & 10.8 & 6 & \multirow{7}{*}{$\begin{array}{l}\text { Jantan } \\
\text { Male }\end{array}$} & 38.2 & 17.0 \\
\hline 8 & & 33.2 & 15.7 & 7 & & 39.7 & 16.5 \\
\hline 9 & & 40.4 & 17.0 & 8 & & 23.5 & 14.0 \\
\hline 10 & & 36.7 & 16.4 & 9 & & 26.2 & 14.5 \\
\hline 11 & & 39.7 & 16.8 & 10 & & 49.8 & 17.3 \\
\hline 12 & & 38.7 & 16.7 & \multirow[t]{2}{*}{11} & & 56.8 & 18.2 \\
\hline 13 & & 29.9 & 15.4 & & & & \\
\hline \multicolumn{2}{|r|}{$\begin{array}{r}\text { Rataan } \pm S D \\
\text { Average } \pm S D\end{array}$} & $33.0 \pm 9.8$ & $15.5 \pm 2.2$ & \multicolumn{2}{|c|}{$\begin{array}{r}\text { Rataan } \pm S D \\
\text { Average } \pm S D\end{array}$} & $39.1 \pm 12.9$ & $16.3 \pm 1.7$ \\
\hline \multicolumn{2}{|c|}{$\begin{array}{l}\text { Total rataan } \pm S D \\
\text { Average total } \pm S D\end{array}$} & $29.6 \pm 11.9$ & $14.8 \pm 2.5$ & \multicolumn{2}{|c|}{$\begin{array}{l}\text { Total rataan } \pm S D \\
\text { Average total } \pm S D\end{array}$} & $50.7 \pm 16.5$ & $17.6 \pm 1.9$ \\
\hline
\end{tabular}


dimasukkan ke dalam mikro tabung steril 1,5 $\mathrm{mL}$. Sampel ditambahkan dengan $250 \mu \mathrm{L}$ buffer lisis $(0,5 \mathrm{M} \mathrm{NaCl} ; 0,001 \mathrm{M}$ EDTA; $1 \%$ SDS; $0,8 \%$ Triton-X; dan 0,1 Tris-HCl pada $\mathrm{pH} 9,0$ ) kemudian $40 \mu \mathrm{L} 10 \%$ SDS dan $40 \mu \mathrm{L}$ Proteinase $\mathrm{K}$ (20 mg/mL). Sampel diinkubasi pada suhu $55^{\circ} \mathrm{C}$ selama 1-3 jam sampai jaringan mengalami lisis dengan sempurna. Kemudian sampel ditambahkan $25 \mu \mathrm{L}$ RNase (larutan $20 \mathrm{mg} / \mathrm{mL}$ ) dan dibiarkan pada suhu ruangan selama 15 30 menit. Sampel ditambahkan $500 \mu \mathrm{L}$ fenol: kloroform:isoamil-alkohol (25:24:1) dan selanjutnya dihomogenkan dengan vorteks. Sampel dibiarkan pada suhu ruangan selama 10 menit sebelum disentrifugasi pada kecepatan 13.000 rpm selama empat menit. Supernatan yang terbentuk dipindahkan ke tabung mikro baru, kemudian ditambahkan lagi $500 \mu \mathrm{L}$ fenol: kloroform:isoamil-alkohol $(25: 24: 1)$ dan disentrifugasi kembali pada kecepatan 13.000 rpm selama empat menit. Supernatan ditambahkan dengan satu kali volume kloroform: isoamilalkohol (24:1) dan selanjutnya disentrifugasi dengan kecepatan $13.000 \mathrm{rpm}$ selama dua menit. Supernatan dipresipitasi dengan etanol absolut dingin dengan membolak-balikkan tabung mikro kemudian disentrifugasi pada kecepatan $6.000 \mathrm{rpm}$ selama 30 menit. Pelet yang terbentuk dicuci dengan $1 \mathrm{~mL}$ etanol $70 \%$ dan kemudian disentrifugasi pada kecepatan 6.000 rpm selama 15 menit. Pelet DNA dikering-udarakan sekitar 20 menit, kemudian ditambahkan dengan $50 \mu \mathrm{L}$ TE buffer agar pelet DNA dapat larut sempurna dan selanjutnya disimpan dalam freezer (suhu $-20^{\circ} \mathrm{C}$ ) sampai digunakan untuk proses selanjutnya. Kualitas genom DNA hasil ekstraksi dilihat melalui analisis eletroforesis pada gel agarosa $0,7 \%$ pada $1 \mathrm{X}$ buffer TBE. Kuantitas genom DNA dianalisis dengan metode spektrofotometer menggunakan GeneQuant (SIGMA). Pengukuran kualitas dan kuantitas genom DNA dilakukan pada saat setelah ekstraksi.

\section{Ekstraksi Total RNA}

Total RNA diekstraksi dengan menggunakan kit isogen (Nippon Gen) dengan cara seperti yang dijelaskan oleh Parenrengi et al. (2009b). Sebanyak 25 mg otot/daging udang windu dimasukkan ke dalam tabung mikro 1,5 $\mathrm{mL}$, kemudian dilarutkan dalam $200 \mu \mathrm{L}$ isogen dalam wadah yang berisi es. Sampel yang sudah digerus dengan grinder tabung mikro ditambahkan kembali isogen hingga volume $800 \mu \mathrm{L}$, kemudian diinkubasi dalam suhu ruang selama lima menit agar sampel dapat terlisis sempurna. Sampel ditambahkan dengan 200 $\mu \mathrm{L}$ kloroform kemudian divorteks dan dibiarkan kembali dalam suhu ruangan selama 2-3 menit. Selanjutnya sampel disentrifugasi dengan kecepatan $12.000 \mathrm{rpm}$ selama sepuluh menit kemudian disimpan pada suhu ruangan selama lima menit dan supernatan yang terbentuk dipindahkan ke dalam tabung mikro baru yang telah berisi $400 \mu \mathrm{L}$ iso-propanol. Sampel dihomogenkan dengan membolak-balikkan tabung mikro secara perlahan dan dibiarkan dalam suhu ruangan selama 5-10 menit. Sampel disentrifugasi kembali pada kecepatan 12.000 rpm pada suhu $4^{\circ} \mathrm{C}$ selama 15 menit. Pelet yang terbentuk dilarutkan dalam $1 \mathrm{~mL}$ etanol $70 \%$ dingin dan disentrifugasi pada kecepatan $12.000 \mathrm{rpm}$ pada suhu $4^{\circ} \mathrm{C}$ selama 15 menit. Supernatan dibuang, pelet dalam tabung mikro dikering-udarakan. Pelet RNA dilarutkan dengan TE buffer sebanyak $50 \mu \mathrm{L}$. Kualitas DNA genom hasil ekstraksi dilihat melalui analisis elektroforesis pada gel agarose $0,7 \%$ pada $1 \mathrm{X}$ buffer TBE, sedangkan kuantitas RNA genom dianalisis dengan metode spektrofotometer menggunakan GeneQuant (SIGMA). Kualitas dan kuantitas total RNA dilakukan pengukuran pada saat setelah ekstraksi.

\section{Rasio RNA/DNA}

Pengukuran konsentrasi DNA dan RNA dilakukan dengan menggunakan GeneQuant. Sebanyak $7 \mu \mathrm{L}$ DNA atau RNA dimasukkan dalam kuvet $5 \mathrm{~mm}$ dengan menggunakan TE buffer sebagai larutan standar. Pengukuran dilakukan pada absorbsi panjang gelombang $260 \mathrm{~nm}$ dan $280 \mathrm{~nm}\left(\mathrm{~A}_{260}\right.$ dan $\left.\mathrm{A}_{280}\right)$. Konsentrasi DNA genom dan RNA dihitung berdasarkan rumus yang dikembangkan oleh Linacero et al. (1998). Konsentrasi RNA $(\mu \mathrm{g} / \mathrm{mL})$ adalah $A_{260}$ x 50 x faktor pengenceran, sedangkan konsentrasi RNA $(\mu \mathrm{g} / \mathrm{mL})$ adalah $A_{260} \times 40 \times$ faktor pengenceran. Kemurnian RNA dan DNA ditentukan berdasarkan rasio antara $A_{260} / A_{280}$. Sedangkan rasio RNA/DNA dihitung dengan cara konsentrasi total RNA dibagi dengan konsentrasi genom DNA.

\section{Analisis Data}

Data rasio konsentrasi RNA/DNA dianalisis menggunakan $t$-test dari program Statistix Versi 3,0 untuk mengetahui perbedaan antara udang windu tumbuh cepat dengan kontrol serta betina dengan jantan pada taraf 0,05. Konsentrasi dan kemurnian RNA dan DNA, serta 
penyimpanan sampel pada suhu $-20^{\circ} \mathrm{C}$ selama 0 , 5, dan 10 hari disajikan secara deskriptif melalui ilustrasi tabel dan gambar. Analisis regresi dilakukan untuk melihat hubungan bobot dan panjang badan dengan rasio RNA/ DNA udang windu.

\section{HASIL DAN BAHASAN}

\section{Ekstraksi DNA Genom dan RNA Total}

Genom DNA dan total RNA berhasil diisolasi dari udang windu tumbuh cepat dan kontrol dengan kemurnian yang cukup tinggi. Uji genomik DNA dan RNA divisualisasikan pada gel agarosa (Gambar 1) untuk beberapa representatif sampel baik dari udang windu tumbuh cepat maupun udang kontrol. Pita tunggal DNA pada posisi bagian atas (> 23.130 bp) merupakan indikator keberhasilan isolasi DNA dengan tingkat kemurnian yang tinggi. Sedangkan RNA diindikasikan dengan adanya latar belakang atau "smear" sepanjang jalur pergerakan khususnya pada bagian bawah. Selain analisis kuantitatif kemurnian RNA berdasarkan rasio $A_{260} / A_{280}$, secara kualitatif (Gambar 1) juga menunjukkan bahwa RNA total yang diisolasi tidak terkontaminasi dengan DNA. Hal tersebut diindikasikan dengan tidak terbentuknya pita tunggal pada posisi genom DNA. Oleh karena itu, pengukuran rasio RNA/
DNA dapat menghasilkan data yang lebih akurat sepanjang total RNA tidak terkontaminasi dengan genom DNA. Gambar 1 juga memperlihatkan bahwa fragmen genom DNA secara kualitatif memperlihatkan pita yang relatif sama antara sampel baik pada udang windu tumbuh cepat (TC) maupun udang windu kontrol (K). Hal yang sama juga diperlihatkan pada visualisasi hasil isolasi total RNA. Oleh karena itu, pengukuran konsentrasi dan kemurnian DNA dan RNA secara kuantitatif sangat perlu dilakukan.

Hasil pengukuran kemurnian DNA dan RNA pada udang cepat tumbuh masing-masing

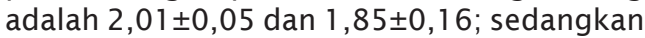
pada udang kontrol adalah 2,04 $\pm 0,05$ dan

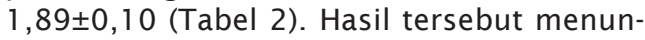
jukkan bahwa kemurnian DNA dan RNA antara udang tumbuh cepat dan kontrol tidak memperlihatkan perbedaan yang berarti, tetapi secara umum nilai kemurnian RNA yang didapatkan relatif lebih kecil dibandingkan dengan nilai kemurnian DNA. Bagi keperluan analisis molekuler DNA dan RNA yang murni ditunjukkan oleh rasio $A_{260} / A_{280}$ yang berkisar antara 1,8-2,0 (Sambrook \& Russel, 1989). Linacero et al. (1998) juga menyarankan tingkat kemurnian DNA genom yang diisolasi sebaiknya berada dalam kisaran 1,8-2,0. Analisis kemurnian genom secara kualitatif

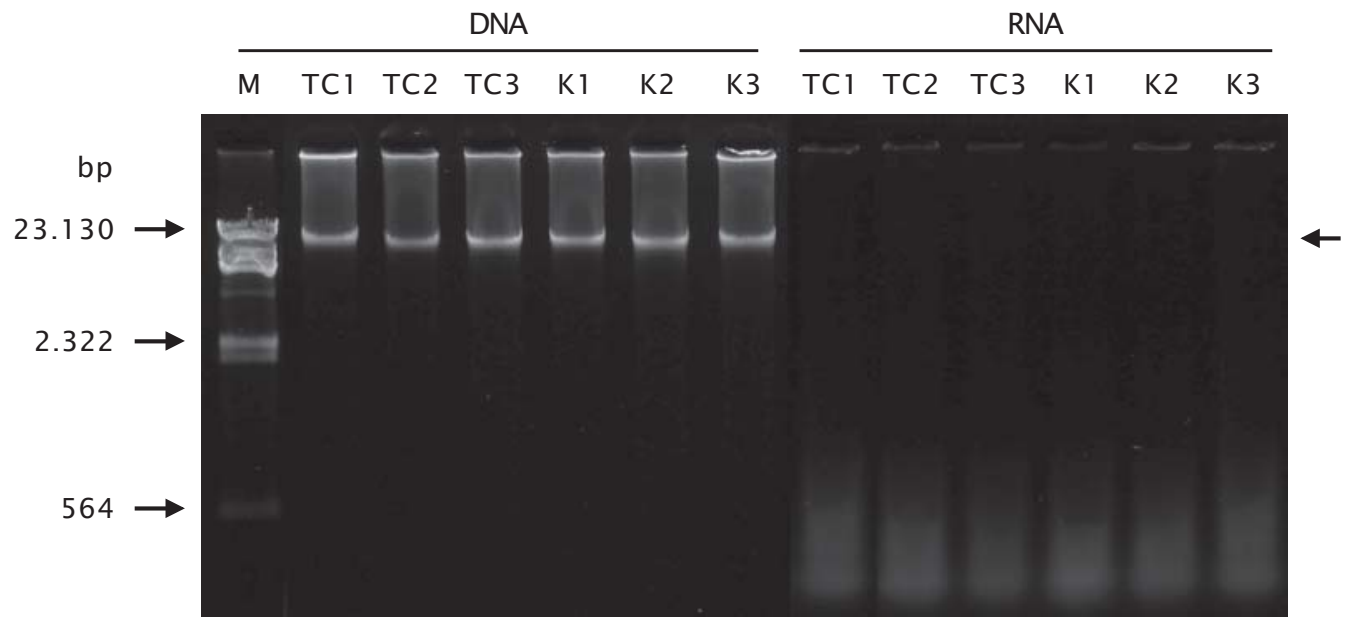

Gambar 1. Genom DNA dan RNA total yang diisolasi dari udang windu P. monodon tumbuh cepat dan kontrol. Marker DNA Hind-III (M); sampel udang windu tumbuh cepat (TC) dan kontrol (K); dan tanda panah menunjukkan posisi fragmen DNA genom

Figure 1. DNA and RNA genome isolated from fast growing and control of black tiger shrimp $\boldsymbol{P}$. monodon (Hind-III DNA marker (M); fast growing black tiger shrimp samples (TC) and control (K); arrow indicated the position of genome DNA fragment 
Tabel 2. Kemurnian dan konsentrasi DNA dan RNA pada udang windu tumbuh cepat dan kontrol Table 2. Purity and concentration of DNA and RNA from fast growing and control black tiger shrimp

\begin{tabular}{lcc}
\hline \multicolumn{1}{c}{$\begin{array}{c}\text { Parameter } \\
\text { Parameters }\end{array}$} & $\begin{array}{c}\text { Udang windu tumbuh cepat } \\
\text { Fast growing tiger shrimp }\end{array}$ & $\begin{array}{c}\text { Udang windu kont rol } \\
\text { Control tiger shrimp }\end{array}$ \\
\hline $\begin{array}{l}\text { Kemurnian DNA } \\
\text { DNA Purity (A260/A280) }\end{array}$ & $2.01 \pm 0.05$ & $2.04 \pm 0.05$ \\
$\begin{array}{l}\text { Kemurnian RNA (RNA Purity) } \\
\text { Konsentrasi DNA }\end{array}$ & $1.85 \pm 0.16$ & $1.89 \pm 0.10$ \\
$\begin{array}{l}\text { DNA concentration }(\mu \mathrm{g} / \mathrm{mL}) \\
\text { Konsentrasi RNA } \\
\text { RNA concentration }(\mu \mathrm{g} / \mathrm{mL})\end{array}$ & $47.06 \pm 24.22$ & $56.02 \pm 39.53$ \\
\hline
\end{tabular}

telah dijelaskan oleh Linacero et al. (1998) berdasarkan karakteristik pita genom pada gel agaros. Pita genom DNA yang bersih tanpa ada fragmentasi pita atau smear mengindikasikan tingkat kemurnian DNA yang baik (DNA tidak terdegredasi serta terkontaminasi). Kontaminasi protein selain ditandai dengan rendahnya nilai kemurnian DNA $(<1,8)$ atau sebaliknya, adanya kontaminasi fenol dan bahan organik lainnya, selain ditandai dengan tingginya nilai rasio $A_{260} / A_{280}(>2,0)$ juga dapat dilihat dengan munculnya latar belakang yang smear di sepanjang jalur pergerakan pita DNA. Kontaminasi RNA pada DNA diindikasikan dengan adanya pita yang kabur pada posisi berat molekul yang rendah.

Kemurnian DNA dan RNA hasil isolasi sangat terkait dengan metode ekstraksi yang digunakan, spesies organisme, jenis jaringan yang diekstrak, metode preservasi, dan lainlain sebagainya. Triana (2010) melaporkan bahwa kemurnian DNA ikan kerapu macan Epinephelus fuscoguttatus yang didapatkan dengan menggunakan kit komersial untuk ekstraksi adalah 1,725-1,904. Isolasi DNA dengan menggunakan metode konvensional pada ikan juga telah dilaporkan oleh Achmad (2009) dengan tingkat kemurnian yang cukup tinggi yaitu $1,996-2,550$ pada ikan nila Oreochromis niloticus dan 1,887-2,166 pada ikan gurame Osphronemus gouramy. Peningkatan kemurnian DNA pada organisme yang relatif sulit seperti rumput laut Kappaphycus alvarezii telah dilakukan dengan modifikasi metode konvensional melalui penambahan kalium asetat (Parenrengi et al., 2006), dengan penambahan tersebut didapatkan kemurnian
1,89 $\pm 0,18$ lebih baik dibandingkan dengan tanpa penambahan kalium asetat $(1,43 \pm 0,34)$.

Ekstraksi DNA menggunakan metode fenol kloroform telah banyak dilaporkan pada penelitian sebelumnya. Ekstraksi DNA pada rumput laut Gracilaria verrucosa memperlihatkan pita genom DNA yang lebih bersih dengan menggunakan metode konvensional fenol kloroform dibandingan dengan beberapa metode ekstraksi yang dicobakan (Parenrengi et al., 2003). Sejumlah kajian RAPD telah memperlihatkan keberhasilan isolasi DNA menggunakan metode fenol kloroform pada beberapa jenis ikan. Bardakci \& Skibinski (1994); Dinesh et al. (1996); Harris et al. (1991); dan Mwanja et al. (1996) telah merekomendasikan penggunaan metode tersebut dalam ekstraksi DNA ikan tilapia. Sementara itu, ekstraksi DNA menggunakan metode fenol kloroform pada ikan belacak, Periopthalmus schlosseri (Shima, 1999) dan ikan kerapu, Epinephelus spp. (Parenrengi et al., 2000) memperlihatkan pita genom DNA yang lebih baik dibandingkan dengan beberapa metode kit yang dicobakan. Dengan teknik elekroforesis, kontaminasi, dan kerusakan genom hasil eksraksi dapat diketahui.

Konsentrasi DNA yang didapatkan pada penelitian ini adalah bervariasi dari 7,7-81 $\mu \mathrm{g} /$ $\mathrm{mL}$ dengan rata-rata $47,06 \pm 24,22 \mu \mathrm{g} / \mathrm{mL}$ pada udang windu tumbuh cepat dan 16,7-100,3 $\mu \mathrm{g} / \mathrm{mL}$ dengan rata-rata $56,02 \pm 39,53 \mu \mathrm{g} / \mathrm{mL}$. Sementara konsentrasi RNA adalah 92,6-199,6 $\mu \mathrm{g} / \mathrm{mL}$ dengan rata-rata $146,18 \pm 38,10$ pada udang windu tumbuh cepat dan 98,0-349,2 $\mu \mathrm{g} / \mathrm{mL}$ dengan rata-rata $137,65 \pm 67,38 \mu \mathrm{g} / \mathrm{mL}$ (Tabel 2). Hal tersebut menunjukkan bahwa 
konsentrasi RNA yang didapatkan relatif lebih tinggi dibandingkan dengan konsentrasi DNA, sedangkan variasi konsentrasi DNA lebih stabil dibandingkan dengan variasi RNA yang diisolasi dari daging udang windu. Hasil analisis tersebut merupakan indikator stabilnya kandungan DNA pada jaringan daging. Soewardi (2007) menyatakan bahwa kandungan DNA relatif konstan dalam sel, sedangkan kandungan RNA bervariasi terkait dengan laju sintesis protein yang terjadi pada individu. Oleh karena itu, jaringan yang paling baik sebagai indikator untuk menentukan kandungan rasio RNA/DNA adalah otot putih (daging warna putih). Parenrengi et al. (2006) melaporkan bahwa konsentrasi DNA yang didapatkan adalah relatif sama pada rumput laut K. alvarezii yakni $218,8 \pm 21,37 \mu \mathrm{g} / \mathrm{mL}$ dengan menggunakan metode ekstraksi konvensional fenol kloroform dengan modifikasi.

\section{Rasio RNA/DNA}

Nilai rasio RNA/DNA yang didapatkan pada udang windu tumbuh cepat $(4,51)$ lebih tinggi dibandingkan dengan udang kontrol $(3,19)$ (Gambar 2A). Hasil analisis $t$-test menunjukkan bahwa rasio RNA/DNA udang windu tumbuh cepat berbeda nyata $(P<0,05)$ dengan rasio RNA/DNA kontrol. Hasil tersebut menunjukkan bahwa pertumbuhan yang cepat pada udang windu dapat diukur dengan menggunakan indikator rasio RNA/DNA. Hasil penelitian ini mengindikasikan bahwa marker DNA yang digunakan dalam program seleksi udang windu tumbuh cepat memiliki peran penting dalam pertumbuhan. Walaupun belum diketahui secara pasti gen yang berperan dalam pertumbuhan udang windu, hasil seleksi diduga memiliki kemampuan yang lebih tinggi dalam pembentukkan sintesis protein yang terkait dengan peningkatan laju pertumbuhan udang windu. Nilai rasio RNA/DNA yang didapatkan pada penelitian ini relatif lebih tinggi dengan nilai yang didapatkan pada larva udang windu yang berkisar 0,00-2,00 (Haryanti et al., 2006). Hasil penelitian tersebut menunjukkan bahwa rasio RNA/DNA larva udang penaeid relatif sama, yakni udang windu $P$. monodon $0,28-0,71$; udang vaname $L$. vannamei 0,46 0,65 ; udang $L$. stylirostris $0,46-0,65$; udang putih $P$. merguensis 0,26; dan udang pama $P$. semisulcatus 0,54 . Perbedaan nilai rasio RNA/ DNA tersebut dapat disebabkan karena perbedaan metode ekstraksi (pengukuran nukleotida), spesies, dan umur organisme. Perbedaan metode pengukuran nukleotida larva ikan gobi memperlihatkan perbedaan konsentrasi log RNA dan log rasio RNA/DNA, tetapi tidak memperlihatkan perbedaan pada log konsentrasi DNA (Esteves et al., 2000). Analisis rasio RNA/DNA pada benih kerapu bebek $C$. altivelis telah dilakukan pada berbagai ukuran dan sumber benih yang dikaitkan dengan penilaian morfologi larva (Anonim, 2010). Hasil penelitian menunjukkan bahwa ada hubungan antara penilaian secara morfologi terhadap nilai rasio RNA/DNA pada benih ikan kerapu bebek. Selain itu, rasio RNA/ DNA sangat erat kaitannya dengan pemuasaan pada ikan. Rossi-Wongtschowski et al. (2003) melaporkan bahwa rasio RNA/DNA semakin rendah didapatkan pakan ikan sardin $S$. brasiliensis yang dipuasakan dibandingan dengan ikan yang diberi pakan secara normal.
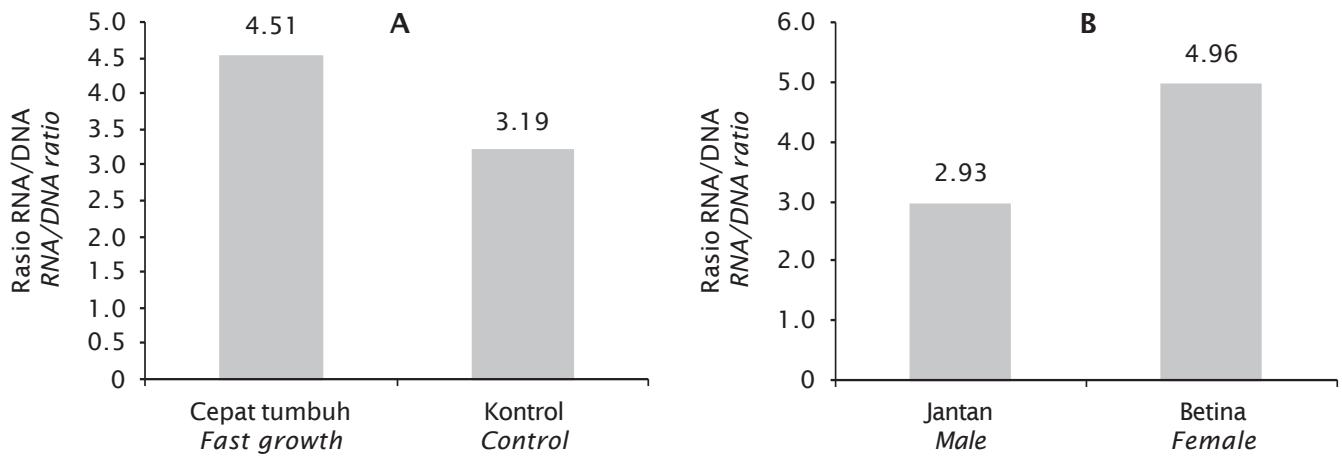

Gambar 2. Rasio RNA/DNA pada udang windu tumbuh cepat versus kontrol (A) dan jantan versus betina (B)

Figure 2. RNA/DNA ratio of black tiger shrimp between fast growing versus control shrimp (A) and male versus female 
Rasio RNA/DNA udang windu yang didapatkan pada penelitian ini adalah 4,96 pada betina dan 2,93 pada jantan (Gambar 2B). Hasil analisis $t$-test rasio RNA/DNA antara jantan dan betina berbeda secara nyata $(P<0,05)$ dengan rasio RNA/DNA jantan udang windu. Udang betina umumnya memperlihatkan laju pertumbuhan yang lebih cepat daripada udang jantan. Perbedaan pertumbuhan udang betina dan udang jantan diduga disebabkan oleh jumlah atau laju sintesis protein pada betina lebih cepat atau ada gen tertentu yang mungkin terkait dengan produksi hormon dan enzim yang dimiliki betina sehingga mempercepat pertumbuhannya. Hal tersebut sejalan dengan pernyataan Soetomo (1990) bahwa udang betina lebih cepat tumbuh daripada udang jantan, sehingga pada umur yang sama udang betina lebih besar daripada jantan. Kamler (1992) juga mengungkapkan bahwa pertumbuhan dan perkembangan organisme merupakan hasil interaksi antara faktor internal dan eksternal. Faktor internal meliputi gen, nutrisi, hormon, enzim, dan lain-lain, sedangkan faktor eksternal adalah lingkungan. Efek jenis kelamin pada ikan dalam pengamatan indeks DNA khususnya rasio RNA/DNA telah dilaporkan oleh Chicharo et al. (2007). Penelitian tersebut membuktikan bahwa rasio RNA/ DNA berbeda antara betina dan jantan pada ikan Pomatoschistus microps, krustase Crangon crangon, dan kekerangan Ruditapes decusatus. Rasio RNA/DNA lebih tinggi didapatkan pada krustase betina dibandingkan dengan jantan. Chicharo \& Chicharo (2008) menyatakan bahwa perbedaan rasio RNA/DNA dapat disebabkan karena adanya perbedaan dimorphisme seks, fisiologi, dan kebiasaan antara betina dan jantan. Kecepatan laju pertumbuhan udang windu yang lebih tinggi pada betina dibandingkan jantan juga sebelumnya telah dilaporkan (Bima, 1989). Hal yang sama juga dilaporkan bahwa, pertumbuhan ikan betina lebih cepat dibandingkan dengan ikan jantan telah dibuktikan pada ikan mata besar Priacanthus macracanthus dan pada ikan trout, tetapi hal berbeda juga dilaporkan bahwa jantan memiliki laju pertumbuhan yang lebih besar dibandingkan betina pada ikan kakap Lutjanus spp., ikan lele, dan lobster Panulirus homarus (Anonim, 2012).

Pengembangan analisis rasio RNA/DNA sudah mulai melihat peluang sebagai indikator dalam mendukung program pemuliaan udang windu. Hasil penelitian Cangara (2010) menun- jukkan bahwa rasio RNA/DNA pada perkawinan induk udang windu antar daerah yang berbeda lebih tinggi dibandingkan dengan rasio RNA/ DNA hasil perkawinan antar daerah yang sama. Variasi rasio RNA/DNA pada larva ikan-ikan laut memperlihatkan perbedaan yang signifikan antara beberapa jaringan. Penelitian Olivar et al. (2009) menunjukkan bahwa jaringan kepala, badan, daging, usus, dan seluruh badan (campuran) memperlihatkan nilai rasio RNA/DNA dengan nilai tertinggi didapatkan pada usus dan terendah pada bagian kepala. Selain itu, penelitian tersebut mengungkapkan bahwa perbedaan spesies larva ikan laut juga memperlihatkan rasio RNA/DNA yang berbeda antara ikan Sardina pilchardus, Engraulis encrasicolus, Atherina presbyter, dan Paralichthys orbignyanus.

\section{Hubungan Antara Rasio RNA/DNA dengan Ukuran Badan}

Ukuran bobot dan panjang badan merupakan parameter morfologi yang paling banyak dan sangat mudah diukur untuk mengetahui laju pertumbuhan udang windu. Bobot dan panjang udang windu memperlihatkan hubungan yang erat dan ada kecenderungan semakin besar bobot dan panjang ukuran udang semakin besar juga nilai rasio RNA/DNA baik pada udang windu tumbuh cepat maupun kontrol (Gambar 3). Dibandingkan dengan panjang badan, bobot udang windu memiliki hubungan yang relatif erat dengan rasio RNA/ DNA. Gambar 3 memper-lihatkan bahwa nilai R $^{2}$ untuk bobot adalah 0,4937 (tumbuh cepat) dan 0,3183 (kontrol), sedangkan untuk panjang memiliki nilai $R^{2}$ adalah 0,4220 (tumbuh cepat) dan 0,2385 (kontrol).

Jika data bobot dan panjang dianalisis dengan tidak membedakan udang windu cepat tumbuh dan kontrol, maka secara umum bahwa rasio RNA/DNA sangat terkait dengan ukuran badan udang windu khususnya bobot dan panjang. Gambar 4 mengungkapkan bahwa semakin besar ukuran badan udang windu semakin tinggi rasio RNA/DNA-nya. Haryanti et al. (2006) melaporkan bahwa performa (nilai morfologi) larva udang windu memiliki korelasi dengan rasio RNA/DNA, dan ada indikasi bahwa semakin baik nilai morfologi larva semakin tinggi nilai rasio RNA/DNA udang windu tersebut. Meskipun demikian, hal yang berbeda juga dilaporkan oleh Haryanti et al. (2006) bahwa ada kecenderungan pada larva udang windu dari Bali, Jawa Timur, Jawa 

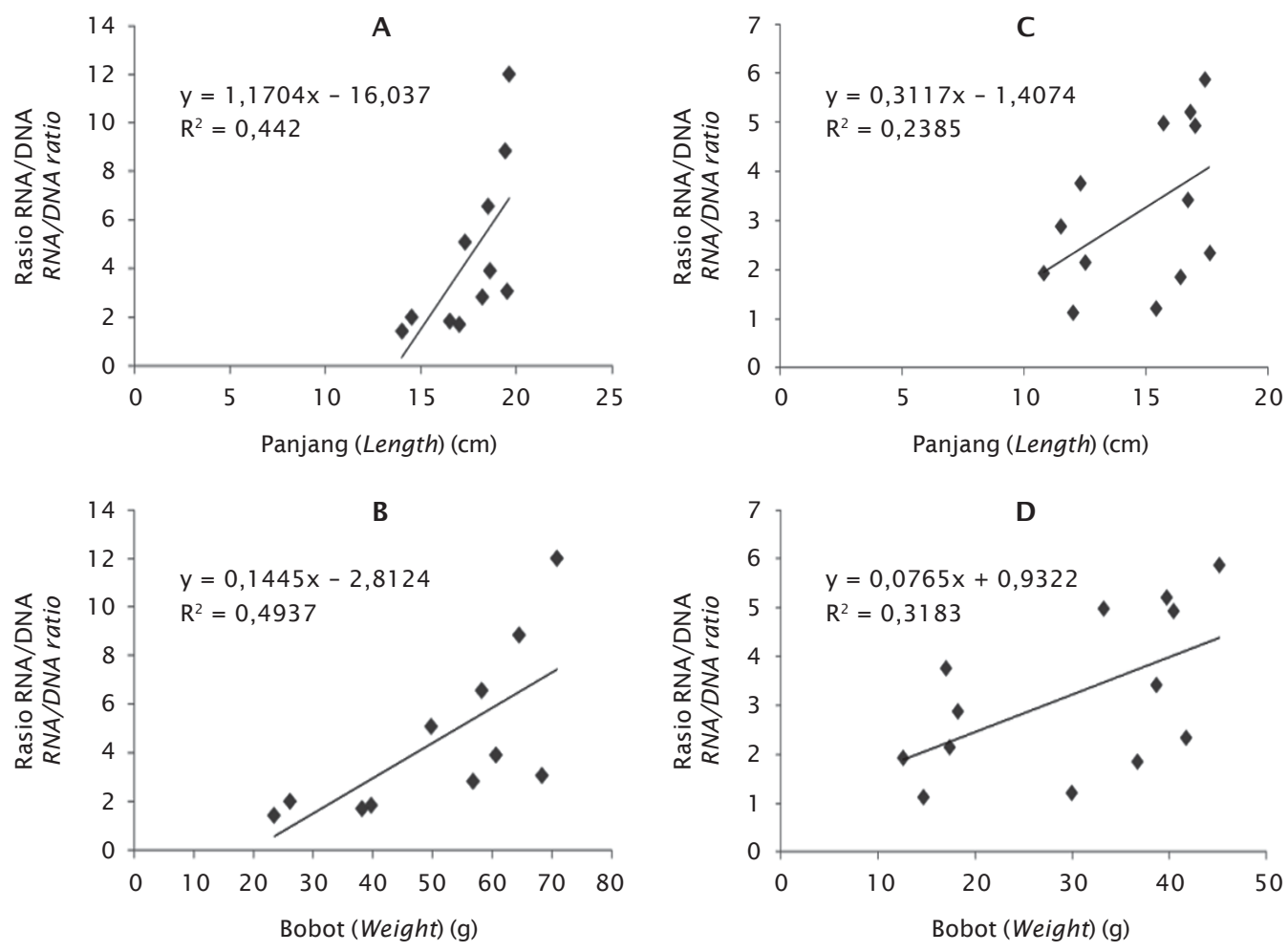

Gambar 3. Hubungan antara rasio RNA/DNA dengan panjang dan bobot badan pada udang windu P. monodon tumbuh cepat (A dan B) dan kontrol (C dan D)

Figure 3. Relationship between RNA/DNA ratio with body length and weight on fast growing (A and $B)$ and control (C and D) of black tiger shrimp P. monodon

Tengah, dan Sulawesi Selatan memperlihatkan pola penurunan rasio RNA/DNA dengan semakin besarnya ukuran benih udang windu.

Gambar 4 memperlihatkan bahwa rasio RNA/DNA memiliki korelasi yang erat dengan bobot $\left(R^{2}=0,4277\right.$ atau $\left.R=0,6502\right)$ dan panjang $\left(R^{2}=0,3168\right.$ atau $\left.R=5,628\right)$ badan udang windu. Hal yang serupa dilaporkan oleh Dewantoro (2001), dari hasil penelitian menunjukkan bahwa hubungan antara rasio RNA/ DNA ikan mas pada umur 1-45 hari memperlihatkan korelasi positif terhadap laju pertumbuhan bobot spesifik dengan tingkat keeratan yang tinggi $(R>0,5)$. Meskipun demikian pada ikan mas yang berumur 45-90 hari, hampir seluruh perlakuan tidak memperlihatkan hubungan yang erat antara rasio RNA/DNA dengan laju pertumbuhan bobot mutlak dan spesifik. Chicharo \& Chicharo (2008) melaporkan bahwa analisis regresi antara kandungan RNA dan DNA dengan panjang cangkang pada moluska (clam)
Ruditapes decussatus memperlihatkan hubungan yang erat dengan nilai $r$ berkisar antara 0,88-0,98. Hal yang serupa dilaporkan oleh Pepin et al. (1999) bahwa konsentrasi DNA memiliki hubungan yang tinggi dengan panjang badan larva ikan Mallotus villosus, Tautogolabrus adspersus, dan Ulvaria subbifurcata, di mana semakin panjang larva ikan semakin besar konsentrasi DNA yang didapatkan. Pada ikan tuna sirip biru Thunnus orientalis, rasio RNA/DNA memperlihatkan korelasi linear dengan panjang badan yang terkait dengan umur larva (Tanaka et al., 2007). Rasio RNA/DNA ikan tuna sirip biru yang didapatkan adalah $3,77 \pm 0,58$ pada umur larva 13 hari dan nilai tersebut meningkat menjadi $19,11 \pm 4,27$ pada larva umur 23 hari.

\section{KESIMPULAN DAN SARAN}

- Ukuran udang windu (bobot dan panjang) memiliki korelasi yang erat $(R>0,5)$ dengan rasio RNA/DNA. 

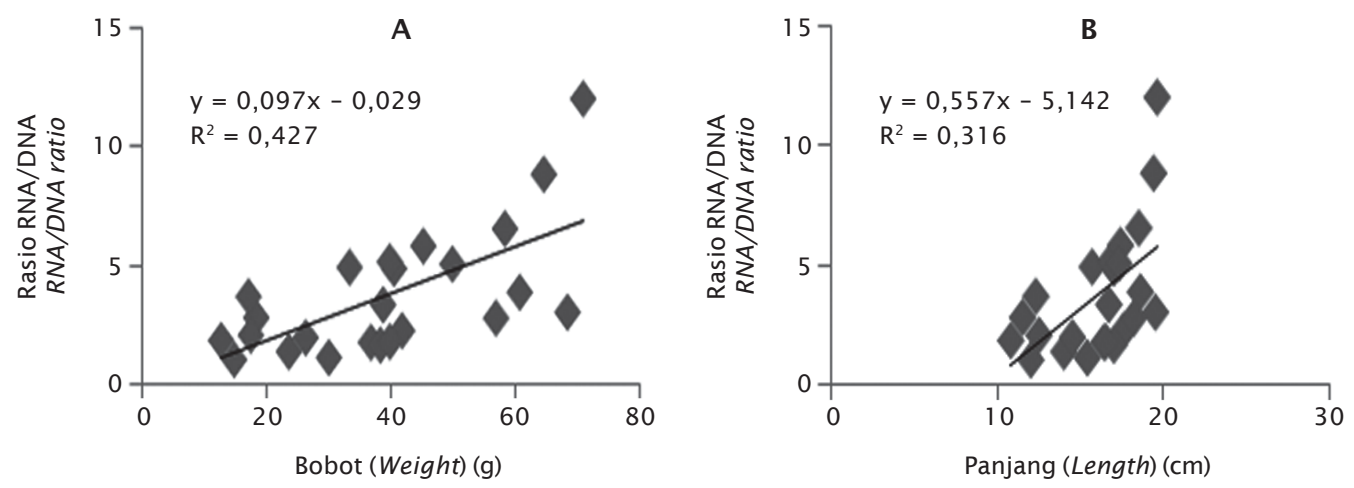

Gambar 4. Hubungan antara rasio RNA/DNA dengan bobot badan (A) dan panjang (B) udang windu P. monodon

Figure 4. Relationship between RNA/DNA ratio with body weight $(A)$ and length $(B)$ of black tiger shrimp P. monodon

- Nilai rasio RNA/DNA udang windu tumbuh cepat lebih tinggi $(4,51)$ dari udang windu kontrol $(3,19)$, demikian halnya dengan nilai rasio RNA/DNA udang windu betina lebih tinggi $(4,96)$ dibandingkan dengan jantan $(2,93)$.

\section{UCAPAN TERIMA KASIH}

Penelitian ini dibiayai oleh DIPA Balai Penelitian dan Pengembangan Budidaya Air Payau, Maros, Tahun Anggaran 2012. Terima kasih diucapkan kepada Mariyuliana, S.Pi., Enti Karnila, Ike Ikarti, Sarah, dan teknisi Lab. Bioteknologi BPPBAP Maros atas bantuannya dalam pelaksanaan penelitian ini.

\section{DAFTAR ACUAN}

Achmad, M. 2009. Pengembangan marka molekuler DNA dalam identifikasi sel gonad ikan gurame (Osphronemus gouramy) dan ikan nila (Oreochromis niloticus) menggunakan PCR. Tesis Magister Sains pada Program Studi IImu Perairan, Institut Pertanian Bogor. $50 \mathrm{hlm}$.

Anonim. 2010. Analisis rasio RNA/DNA protein benih kerapu bebek, Cromileptes altivelis. Laporan Balai Besar Riset Perikanan Budidaya Laut, Gondol-Bali, $1 \mathrm{hlm}$.

Anonim. 2012. Mana yang lebih cepat tumbuh: individu jantan atau betina?. Http://arsipperikanan.blogspot.com/2012/04. $2 \mathrm{hlm}$.

Bardakci, F. \& Skibinski, D.O.F. 1994. Application of the RAPD technique in tilapia fish: species and subspecies identification. $\mathrm{He}$ redity, 73: 117-123.
Bima, M. 1989. Studi tentang pertumbuhan udang windu (Penaeus monodon, Fabricius) di tiga tambak proyek pandu tambak inti rakyat. Skripsi Jurusan Manajemen Sumberdaya Perairan, Fakultas Perikanan, Institut Pertanian Bogor, $101 \mathrm{hlm}$.

Buckley, L.J. 1984. RNA-DNA ratio: an index of larval fish growth in the sea. Marine Biology, 80: 291-298.

Caldarone, E.M., Onge-Burns, J.M.S., \& Buckley, L.J. 2003. Relationship of RNA/DNA ratio and temperature to growth in larvae of Atlantic cod Gadus morhua. Marine Ecology Progress Series, 262: 229-240.

Chicharo, L.M.Z. \& Chicharo, M.A.A.T. 1995. The DNA/RNA ratio as a useful indicator of the nutritional condition in juveniles of Ruditapes decussatus. Scientia Marina, 59: 91-101.

Chicharo, M.A., Chicharo, L., Amaral, A., \& Morais, P. 2007. Sex effect on ratios and concentrations of DNA and RNA three in marine organism. Marine Ecology Progress Series, 332: 241-245.

Chicharo, M.A. \& Chicharo, L. 2008. RNA:DNA ratio and other nucleid acid derivated indices in marine ecology. International Journal of Molecular Science, 9: 1,453-1,471.

Cangara, A.S. 2010. Perkembangan, pertumbuhan, dan rasio RNA/DNA larva udang windu (Penaeus monodon) hasil perkawinan induk dari lokasi yang berbeda. Tesis Pascasarjana. Universitas Hasanuddin, Makassar, $71 \mathrm{hlm}$.

Dewantoro, E. 2001. Rasio RNA/DNA, karakter 
morfometrik, dan komposisi daging ikan mas (Cyprinus carpio L.) strain sinyonya, kerper kaca, dan hibridanya. Tesis Program Pascasarjana, Institut Pertanian Bogor.

Dinesh, K.R., Lim, T.M., Chan, W.K., \& Phang, V.P.E. 1996. Genetic variation infered from RAPD fingerprinting in three species of tilapia. Aquaculture International, 4: 19-30.

Esteves, E., Chicharo, M.A., Pina, T., Coelho, M.L., \& Andrade, J.P. 2000. Comparison of RNA/ DNA ratios obtained with two methods for nucleic acid quantification in gobiid larvae. Journal of Experimental Marine Biology and Ecology, 245: 43-55.

Harris, A.S., Bieger, S., Doyle, R.W., \& Wright, J.M. 1991. DNA fingerprinting of tilapia, Oreochromis niloticus and its applications to aquaculture genetics. Aquaculture, 92: 157-163.

Haryanti, Mahardika, K., Moria S.B., \& Permana, I G.N. 2006. Study on fry performance of black tiger shrimp Penaeus monodon with spacial reference to its morphological and RNA/DNA ratio analysis. Indonesian Aquaculture Journal, 1(2): 159-164.

Haryanti, Muzaki, A., Wardana, I K., Fachrudin, Moria, S.B., \& Permana, I G.N. 2009. Phenotypic and genotypic performance of black tiger shrimp, Penaeus monodon having fast growth traits. Indonesian Aquacuture Journal, 4(2): 101-108.

Haryanti. 2011 . Penggunaan marka molekular dalam menghasilkan induk unggul udang. Makalah disampaikan pada Pertemuan Jaringan Udang Vanname Nusantara I. Denpasar, 16-18 November $2011.31 \mathrm{hlm}$.

Haines, T.A. 1973. An evaluation of RNA-DNA ratio as a measure of long-term growth in fish populations. Fisheries Research Board of Canada, 30(2): 195-199.

Kamler, E. 1992. Respiration and metabolism in fish and fisheries, series 13, Fish Bioenergetics. Chapman and Hall, London.

Linacero, J., Rueda, \& Vazquez, A.M. 1998. Quantification of DNA. Isaac, G., Ingram, D.S., (Eds.). Molecular Tools for Screening Biodiversity: Plants and Animals. Chapman and Hall. London, Weinheim, New York, Tokyo, Melbourne, Madras, p. 18-21.

Mwanja, W., Booton, G.C., Kaufman, L., Chandler, M., \& Fuerst, P. 1996. Population and stock characterization of Lake Victoria tilapine fisher based on RAPD markers. Aqua. Biotech. Symp. Proceeding, p. $115-$ 123.
Olivar, M.P., Diaz, M.V., \& Chicharo, M.A. 2009. Tissue effect on RNA:DNA ratios of marine fish larvae. Scientia Marina, 73: 171-182.

Parenrengi, A., Shamsusin, L., Ismail, P., \& Amin, N.M. 2000. Preliminary study on DNA level marker of grouper at different buffer preservation and DNA extraction method. In: Saad, M.S., Faridah, Q.Z., Kadir, M.A., Khalid, M.Z.Z., Mohamad, O., Saleh, G.B., \& Panandam, J.M. (Eds.). Genetic Manipulation: Challenges and Advantages. Proceeding of the $4^{\text {th }}$ National Congress on Genetics, 2628 September 2000, Genting Highlands, Malaysia, p. 194-208.

Parenrengi, A., Sulaeman, Suryati, E., \& Tenriulo, A. 2003. Karakteristik genetika beberapa sumber rumput laut, Gracilaria verrucosa. Balai Riset Perikanan Budidaya Air Payau, Maros, $11 \mathrm{hlm}$.

Parenrengi, A., Sulaeman, Suryati, E., \& Tenriulo, A. 2006. Karakterisasi genetik rumput laut Kappaphycus alvarezii yang dibudidayakan di Sulawesi Selatan. J. Ris. Akuakultur, 1(1): 1-11.

Parenrengi, A., Alimuddin, Sukenda, Sumantadinata, K., Yamin, M., \& Tenriulo, A. 2009a. Cloning of ProAV promoter isolated from tiger prawn Penaeus monodon. Indonesian Aquaculture Journal, 4(1): 1-7.

Parenrengi, A., Alimuddin, Sukenda, Sumantadinata, K., \& Tenriulo, A. 2009b. Karakteristik Sekuens cDNA Pengkode Gen Antivirus dari Udang Windu, Penaeus monodon. J. Ris. Akuakultur, 4(1): 1-13.

Pepin, P., Evans, G.T., \& Shears, T.H. 1999. Patterns of RNA/DNA ratios in larval fish and their relationship to survival in the field. ICES Journal of Marine Science, 56: 697-706.

Rooker, J.R. \& Holt, G.J. 1996. Application of RNA:DNA ratios to evaluate the condition and growth of larval and juvenile red drum (Sciaenops ocellatus). Marine and Freshwater Research, 47(2): 283-290.

Rossi-Wongtschowski, C.L.D., Clemmesen, C., Ueberschar, B., \& Dias, J.F. 2003. Larval condition and growth of Sardinella brasiliensis (Steindachner, 1879): Preliminary results from laboratory studies. Scientia Marina, 67(1): 13-23.

Sambrook, J. \& Russel, D.W. 1989. Molecular Cloning: A Laboratory Manual. New York: Cold-Spring Harbor Laboratory Press. $2^{\text {nd }}$ edition, $165 \mathrm{hlm}$.

Shima, I. 1999. PCR-RAPD analysis on DNA of mudskipper, Periphthalmus schlosseri 
(Pallas). Faculty of Applied Science and Technology, Universiti Putra Malaysia, 62 pp.

Soetomo, M. 1990. Teknik budidaya udang windu: Kajian sistem resirkulasi tertutup menggunakan biofilter bivalvia dan makroalga pada pembesaran udang windu (Penaeus monodon). Fakultas Perikanan dan Ilmu Kelautan, Universitas Padjajaran.

Soewardi, K. 2007. Pengelolaan keragaman genetik sumberdaya perikanan dan kelautan. Departemen Manajemen Sumberdaya Perairan, Fakultas Perikanan dan Ilmu Kelautan, Institut Pertanian Bogor, Bogor, $153 \mathrm{hlm}$.
Tanaka, Y., Gwak, W.S., Tanaka, M., Sawada, Y., Okada, T., Miyashita, S., \& Kumai, H. 2007. Ontogenetic changes in RNA, DNA and protein contents of laboratory-reared Pacific bluefin tuna Thunnus orientalis. Fisheries Science, 73: 378-384.

Tonnek, S., Syafaat, N., \& Haryanti. 2011. Penelitian performansi larva udang windu tumbuh cepat dan upaya seleksi calon induk di tambak. Laporan Balai Penelitian dan Pengembangan Budidaya Air Payau, Maros, $7 \mathrm{hlm}$.

Triana, S.H. 2010. Analisis Fragmen DNA Ikan Kerapu Macan (Epinephelus fuscoguttatus) yang Tahan dan Rentan terhadap Bakteri Vibrio alginolyticus. Jurnal IImu Dasar, 11(1): 8-16. 